\title{
BIOLOGICAL BASES OF SEED AND VEGETATIVE REPRODUCTION OF CORNELIAN CHERRY (CORNUS MAS L.) IN NATURE AND CULTURE
}

\author{
Klymenko Svitlana*, Grygorieva Olga, Onyshuk Lyudmila
}

M.M. Gryshko National Botanical Garden of Ukraine of National Academy of Sciences, Kyiv, Ukraine

\begin{abstract}
БИОЛОГИЧЕСКИЕ ОСНОВЫ СЕМЕННОЙ И ВЕГЕТАТИВНОЙ РЕПРОДУКЦИИ КИЗИЛА ОБЫКНОВЕННОГО (CORNUS MAS L.) В ПРИРОДЕ И КУЛЬТУРЕ
\end{abstract}

\author{
Клименко Светлана, Григорьева Ольга, Онищук Людмила
}

Received 25. 6. 2017

Revised 29.6. 2017

Published 27. 11. 2017

Cornelian cherry (Cornus mas L.) is a valuable fruit, medical, decorative, meliorative plant. It is rarely cultivated due to the lack of studies on ways of its seed and vegetative reproduction. In recent decades in Ukraine, as well as in other countries, interest on cornelian cherry has increased significantly, but the demand for cultivar planting material is not being satisfied because of insufficient knowledge of the tested methods of seed and vegetative reproduction. The department of Acclimatization of fruit plants of NBS works on breeding of cornelian cherry, the selection fund of which is represented by several dozen cultivars, 14 of them are entered in the State Register of Plant Cultivars of Ukraine. The methods of seed and vegetative reproduction have been studied. Despite the fact that the seed method of reproduction of the cornelian cherry has not lost its importance for growing the rootstock, as well as seedlings for the creation of forest cultures, during creating mono-gardens from cornelian cherry, vegetative reproduction of promising cultivars is necessary, since the seed method of reproduction doesn't ensure the fixation of all economically valuable characteristics of the cultivars in the progeny. In addition, seedlings begin to bear fruit only for the $6^{\text {th }}-8^{\text {th }}$ year, and vegetative reproduced plants - for the $2^{\text {nd }}-3^{\text {rd }}$ year. Reproduction of the cornelian cherry in nature is caused by the enhanced ability to form the sprouts. This type of formation of young shoots has continued for many tens of years due to the continuous restoration of dying subordinate trunks. We have studied the reproduction of cornelian cherry by spring and summer grafting, lignified and summer cuttings. The emergence of the regenerative ability in the cutting depends on various endogenous and exogenous factors. In the average conditions cornelian cherry doesn't reproduce well by cuttings. However, following factors such as high humidity, sufficient warmth, treatment of cuttings using physiologically active substances increase the percentage of rooting, the overall number of roots and their total length. Cuttings of 10-15 cm length should have 2-4 pairs of leaves. Leaves have a great value for cornelian cherry during the cuttings propagation: the leaf blade doesn't get shorter, hence promoting the fast and intensive growth of roots, in comparison with traditionally prepared cuttings. By the end of the vegetative period the cornelian cherry rooted cuttings are weakly developed and thus are planted for cultivation in the early spring (end of March - beginning of April), with the planting scheme $20 \times 35 \mathrm{~cm}$. By the end of the II vegetative period the cuttings reach height of $70-80 \mathrm{~cm}$, the diameter of the root stocks is $8-10 \mathrm{~mm}$, the plants form 3-4 side shoots and can be planted to a permanent place. The ability of the cornelian cherry to form a large number of sprouts depends on its longevity. The most effective

*Corresponding author: Svitlana Klymenko, M.M. Gryshko National Botanical Garden of Ukraine of National Academy of Sciences, Kyiv, Ukraine, $\triangle$ cornusklymenko@gmail.com 
methods of vegetative reproduction are budding and green cuttings. The yield of planting material during the reproduction of the cornelian cherry by budding is $90-95 \%$, the layers $85-90 \%$, the green cuttings $75-80 \%$, the lignified cuttings $40-60 \%$, the spring graft $40-60 \%$.

Keywords: cornelian cherry; Cornus mas L.; seed and vegetative reproduction; forest-steppe; Ukraine

\section{Введение}

Кизил обыкновенный (Cornus mas L.) - ценноеплодовое илекарственное растение-заслуживает большего внимания в связи с рядом преимуществ перед другими плодовыми культурами: ежегодное стабильное плодоношение, высокая ценность плодов, содержащих необходимые для человека биологически активные вещества (Клименко, 1990, 2000, 2013; Сорта плодовых..., 2013).

Известный в культуре в течение многих столетий кизил выращивается мало. Только в последние десятилетия наблюдается возрождение этого замечательного растения.

Мы считаем, что недостаточное культивирование кизила в промышленных и фермерских садах объясняется отсутствием опробованных способов семенного и вегетативного размножения.

Изучение биологических особенностей размножения растений имеет важное теоретическое - для понимания вопросов филогенеза и онтогенеза и практическое значение - для репродукции растений семенным и вегетативным способами.

В практике садоводства и лесоведения используются разнообразные методы и способы преодоления покоя у семян для размножения и ускоренного получения посадочного материала (Радулов, 1996; Ализаде, 1997). В то же время у многих видов растений способность семян не прорастать сразу после созревания закреплена филогенетически, обеспечивая таким образом сохранение их для воспроизводства потомства (Chopra, 1965).

Способность семян длительное время, не прорастая, сохранять жизнеспособность, является одной из важнейших приспособительных особенностей растений, считает М.Г. Николаева (1967). Основные пути проявления этих особенностей - вынужденный и органический покой семян. Причины, вызывающие его, разные.

У многих видов семена находятся в таком глубоком покое, что в естественных условиях они прорастают только через 1 - 2 года после посева.

Классификация типов семян, разработанная М.Г. Николаевой (1967) построена на основе 2 характеристик - причина торможения прорастания и способ его преодоления. У семян кизила сложный механизм покоя: экзогенный, обусловленный физико-химическими свойствами и эндогенный, связанный с состоянием зародыша. Такой покой называется комбинированным.

В последнее время сформировано несколько моделей стратификации семян плодовых растений (Chopra, 1965; Seely and Damavandy, 1985; Suszka, 2002).

В зависимости от вида растений, вначале семена могут проходить «теплую фазу» при постоянной или циклически-переменной температуре, имитирующей осенние природные условия. А в дальнейшем, независимо от породы, последняя 10 - 16-недельная фаза стратификации всегда проходит на холоде, лучше всего при температуре $+3{ }^{\circ} \mathrm{C}$. Посев семян после окончания стратификации надо проводить не раньше, чем наклюнется треть семян. Польские исследователи (Suszka, 2002) стратификацию семян рекомендуют заканчивать после появления первых проростков у 10 \% семян. После этого семена сеют, а если это невозможно - прорастание можно задержать на несколько недель охлаждением семян до $-3{ }^{\circ} \mathrm{C}$. За 2 - 3 дня до посева такие семена прогревают до $+15-20{ }^{\circ} \mathrm{C}$. Для кизила в начале стратификации температуру рекомендуют циклически менять в пределах $+20 \ldots+30{ }^{\circ} \mathrm{C}$ (Майборода, 2003). 
С целью разработки методов ускоренного прорастания семян кизила работало достаточно много исследователей - А.К. Нароян (1951), С.Н. Литвиненко (1955), А.И. Ильина (1958), Д.Д. Минин (1968), М.Г. Колотова (1982) и др. Использовались различные приемы обработки семян химическими веществами (кислотами, щелочами и др.). Все эти приемы были различны по эффективности прорастания семян. Однако, универсального, легкодоступного метода предпосевной подготовки семян рекомендовано не было. Заслуживают внимание опыты, проведенные Д.Д. Мининым: 10-дневное замачивание семян (с ежедневной сменой воды) и дальнейшей стратификацией во влажном песке в течение 3 месяцев при температуре $20^{\circ} \mathrm{C}$ и в течение 4 месяцев при $0-3^{\circ} \mathrm{C}$. В результате было получено $70-75$ \% всходов.

П.Я. Вановский и Ф.К. Воронцов (1952) рекомендуют методускоренной стратификации в парнике, где температура поднималась до $16-18{ }^{\circ} \mathrm{C}$ благодаря горению навоза. Такую предпосевную подготовку авторы рекомендуют делать за 40 - 45 дней до высева семян в питомник. Они отмечают, что прорастание семян в парнике шло достаточно дружно и быстро.

Обработка семян разными стимуляторами роста способствует сокращению периода стратификации до 7 - 8 месяцев (Іванніков, 1999). Хорошие результаты получены при обработке замоченных семян 0,1 \%-ным раствором гиббереллина в течение недели, а также 0,05 \%-ным раствором этрела в течение суток.

Цель наших исследований - изучение различных способов семенного и вегетативного размножения кизила, оценка эффективности каждого из них.

\section{Материалы и методы}

Объекты исследований - растения кизила селекционного генофонда Национального ботанического сада им. Н.Н. Гришко НАН Украины (НБС) посадки 1985, 1990, 2000 гг. Размножение семенами включали экспериментальные исследования по подзимнему посеву, посеву стратифицированными семенами в условиях традиционной (холодной) подготовки и переменной - тепло-холодной стратификации, посеву летом семенами, извлеченными из незрелых плодов и с околоплодниками.

Вегетативное размножение проводили зелеными черенками, весенней и летней прививкой, для размножения отводками использовали 8 - 10-летние растения. Укоренение зелеными черенками проводили в туманообразующей установке, где автоматически регулируются температура и влажность.

Черенки длиной 12 - 15 см с двумя-четырьмя парами листьев нарезали рано утром из верхней части побега, связывали в пучки по 25 - 30 шт. и помещали в раствор стимулятора ИМК (индолилмасляная кислота) - 25 мг/л при экспозиции 20 - 24 часа или опудривали стимулятором БИ-12. Можно использовать и любые другие стимуляторы с ауксиновой активностью.

Техника окулировки такая же, как и для других плодовых растений - за кору в Т-образный разрез на подвое. Длина продольного разреза коры 1,5 - 2,0 см, поперечного - 1/3 - 1/2 толщины подвоя. Края коры раздвигают и вставляют щиток привоя с тонкой полоской древесины (или без нее) и почкой в середине. Место прививки обвязывают полихлорвиниловой пленкой длиной 20 - 25 см и шириной 1,0 - 1,2 см.

Окулируют также способом вприклад, выполнение которого не связано с состоянием и отделением коры на подвое. Этот способ дает возможность при необходимости продлить сроки окулировки до конца августа и выполнять эту работу даже в сентябре.

Как подвой использовали двухлетние сеянцы кизила, выращенные из семян сортовых растений.

Очень большое значение имеет состояние подвоя и привоя. За неделю перед окулировкой, а если очень сухо, то еще раз за 2 - 3 дня необходимо полить подвой. Для большего выхода посадочного материала при необходимости можно сделать подокулировку. Очень важным 
приемом является своевременное снятие обвязок в годы с хорошими погодными условиями, достаточным количеством осадков, когда подвой продолжает интенсивно расти и до конца сентября - начала октября обвязка сильно врезается в подвой и он может переламываться. После того как обвязка снята, заокулированные сеянцы окучивают, чтобы защитить глазки от подмерзания, особенно в бесснежные зимы.

Технология дальнейшего выращивания заокулированных растений такаяже, каки др. плодовых растений (речь идет о срезании на шип и дальнейшем уходе за растениями).

Размножение весенней прививкой провели способами в боковой зарез, вприклади улучшенной копулировкой.

Отводки на укоренение закладывали в марте - до набухания почек, как только можно было обрабатывать почву. При большом объеме работ отводки можно закладывать и осенью. Для укоренения отводков необходимы постоянная влажность, умеренная температура и хорошо подготовленная почва. Для размножения отводками материнское растение кизила выращивают в виде куста. Молодые побеги в возрасте от 1 до 3 лет, растущие близко к поверхности почвы, укладывают в специально вырытые бороздки, оставляя снаружи загнутый под прямым углом конец длиной около 20 см. Кору под листовым узлом подрезают в том месте, где ветка загибается кверху, это стимулирует корнеобразование. Верхушку ветки прикрепляют к вертикальному колышку, обрезают ее на 1/3 - 1/4 длины, что стимулирует пробуждение нижерасположенных почек. Боковые разветвления обрезают, ветку закрепляют деревянными или проволочными дужками. Сверху ветку засыпают землей, слегка утрамбовывают и поливают. Почву необходимо тщательно подготовить. Глубина бороздки должна быть 12 - 15 см. На бедных почвах бороздки заправляют плодородной почвой или смесью торфа, почвы и песка. За влажностью почвы надо следить, особенно в сухую погоду. Отводки укореняются обычно в течение вегетации. Уход за отводками состоит в рыхлении почвы, подкормке, борьбе с сорняками.

\section{Результаты и их обсуждение}

Семена кизила для размножения заготавливали в августе-сентябре-октябре, когда созревают плоды. В процессе созревания плодов семена (косточка и семя используются как синонимы, так как в практике плодоводства семя из косточки не вынимают) переходят в состояние покоя - вокруг семени формируются плотные покровы косточки и потому, как и семена многих других плодовых растений, требует предпосевной подготовки - стратификации, которая может длиться в зависимости от условий от 11 до 18 месяцев. На стратификацию семена кизила мы закладываем сразу после сбора плодов, не подсушивая их, - в опилки, мох, перегной, обеспечивая постоянное увлажнение.

К сожалению, на практике семена, вынутые из плодов, не сразу закладывают на стратификацию. Это - большая ошибка. В результате часто удлиняются сроки предпосевной подготовки, ухудшается, а иногда и теряется всхожесть семян.

На это еще в 30-е годы прошлого столетия обращал внимание известный украинский ученый Н.Ф. Кащенко (1925). Он писал: «Если семена сеют сразу после сбора, то результаты получают наилучшие. Не высевайте семена деревьев и кустарников ни в какое другое время, как только сразу после сбора».

В наших исследованиях семена, заложенные на стратификацию сразу после извлечения их из плодов, в условиях обычной стратификации прорастают уже через 16 - 17 месяцев. При постоянном промывании сроки предпосевной подготовки можно сократить до 10 - 11 месяцев.

Проведенные нами в течение многих лет исследования по семенному размножению показали, что эндокарп кизила не является препятствием для прорастания семени, так как количество поглощенной им воды на 9 - 11 сутки составляет 125 \% (Клименко, 2000). Интересно, что 
изолированное из эндокарпа семя кизила не прорастает, а изолированные зародыши прорастают на 15 - 19 день (Парфенова, 1974).

Анатомическое его строение свидетельствует о тесной связи с оболочкой семени (рис. 1, 2), а также проходящих в нем сложных биохимических процессах (Erdelska and Szukukalek, 1980; Tylkowski, 1991), в связи с наличием ингибиторов, тормозящих прорастание семени, которые удаляются из него при достаточном обеспечении водой во время подготовки семян к посеву разными способами, что способствует процессу прорастания (Майборода, 2003).

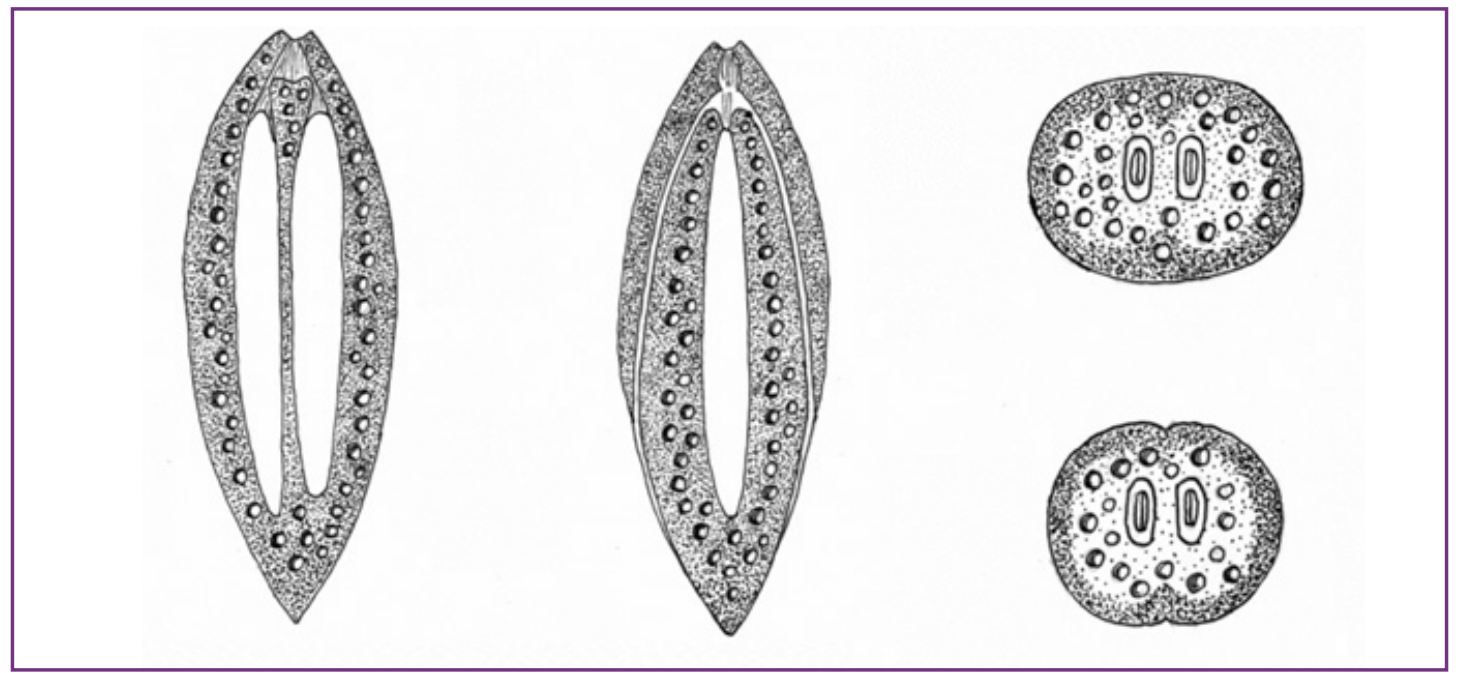

Рисунок 1 Эндокарп кизила. Продольный и поперечный разрезы

Figure 1 Endocarp of cornelian cherry. Longitudinal and transverse sections

(a) A B

Рисунок 2 Семя кизила

А - в эндокарпе; В - извлечено из эндокарпа

Figure 2 Cornelian cherry seed

A - in the endocarp; B - isolated from endocarp 
Традиционно считается, что наиболее благоприятные условия подготовки семян к прорастанию складываются при высокой влажности и хорошем поступлении воздуха во время действия низких положительных температур (Seely, 1985). Для этого в течение всего периода стратификации влажность субстрата поддерживают на уровне 45 - $50 \%$, а температуру в пределах $0 \ldots+5{ }^{\circ} \mathrm{C}$ (холодная стратификация) или $+20-25^{\circ} \mathrm{C}-$ в первые $2-3$ недели и $0 \ldots+5{ }^{\circ} \mathrm{C}$ - до конца рекомендованного периода (тепло-холодная стратификация) (Надточій, 1998).

В наших исследованиях эффективными методами подготовки семян и получения сеянцев были стратификация семян в течение 1 - 2-хлет и посев ихосенью или весной, посев свежесобранными семенами, когда всходы были получены через 18 месяцев после посева. Лучшим из способов проращивания семян в наших исследованиях была двухэтапная стратификация с изменением температурного режима: 3-месячная стратификация при температуре $20-22{ }^{\circ} \mathrm{C}$ и 4-месячная при 0 - $5^{\circ} \mathrm{C}$. В результате через 8 месяцев было получено 70 \% всходов (Клименко, 2000).

Очень важное значение имеет субстрат, используемый для стратификации. В наших исследованиях лучшими были мох и опилки, хуже результаты получены в песке (здесь наблюдается недостаточная аэрация в результате уплотнения песка). Мох и опилки очень хорошо удерживают влагу и достаточно аэрируются.

У кизила, как и у других косточковых, семена из эндокарпа выходит при прорастании. Разница в том, что у кизила при этом открывается только небольшая часть эндокарпа в виде треугольника (рис. 3), а у других косточковых эндокарп распадается на две половины.

Наклюнувшиеся семена кизила надо сеять сразу, так как у переросших семян очень легко отламываются зачаточные корешки (они мясистые и хрупкие) (рис. 3). Глубина заделки семян 2 - 3 см (при осеннем посеве - не менее 5 см) (Клименко, 2000). Семядольные листья у всходов кизила сохраняются до 20 - 25 дней (рис. 4).

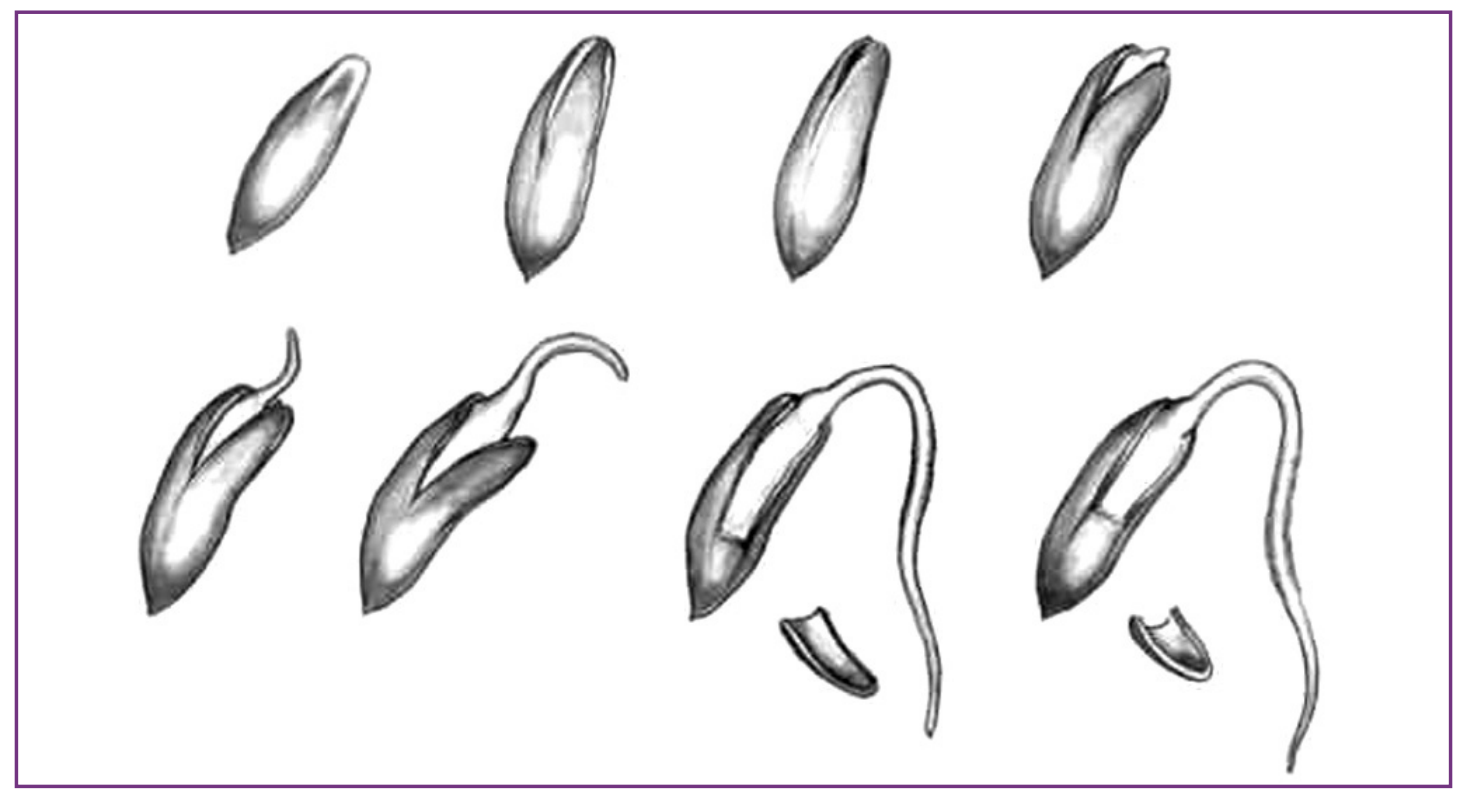

Рисунок 3 Проросшие семена кизила

Figure 3 Germinated seeds of cornelian cherry 

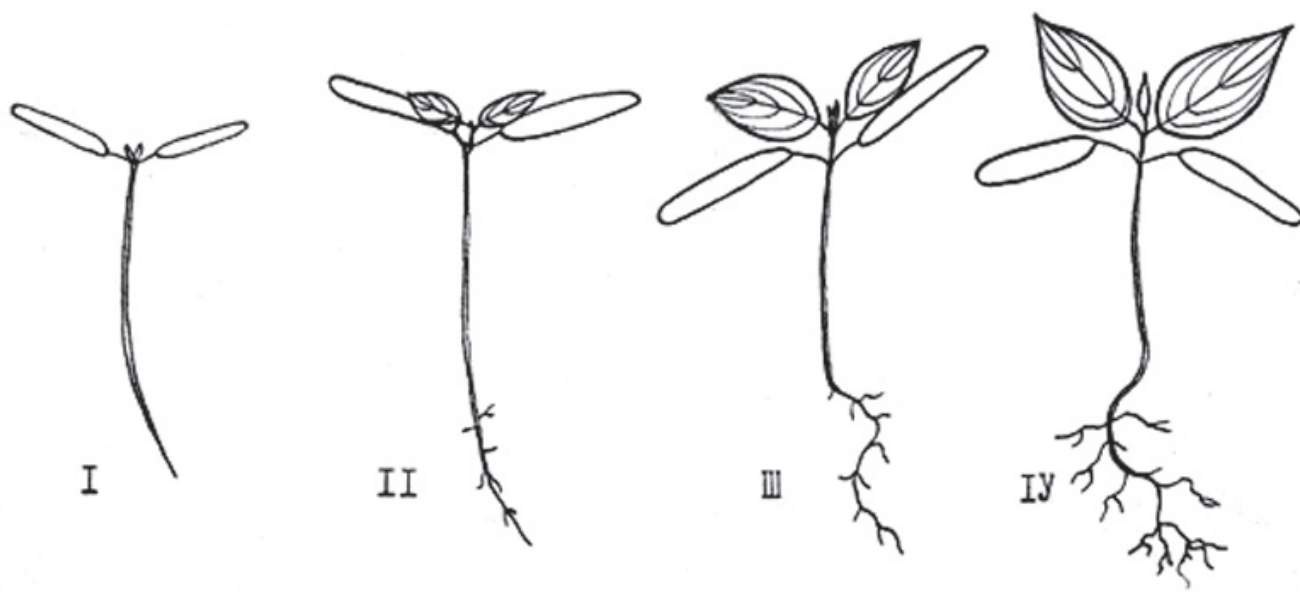

Рисунок 4 Проростки кизила

I - с семядольными листьями, II - начало появления I пары настоящих листьев, III-IV - семядольные листья сохраняются до 20 - 25-дневного возраста

Figure 4 Cornelian cherry seedlings

I - with cotyledon leaves, II - beginning of appearance of the first pair of true leaves, III-IV - cotyledon leaves preserved until age of $20-25$ days

В течение лета сеянцы достигают размеров 35 - 40 см, диметр штамбика у них 0,4 - 0,5 см, в хороших условиях питания и увлажнения эти показатели могут быть значительно выше.

По нашим данным, у дикорастущих и культурных растений кизила наблюдается самосев (в результате автобарохорного опадания плодов) в пределах кроны.

Семенное размножение кизила в природе затруднено в связи с его биологическими особенностями и, прежде всего, требовательностью к освещению, самосев гибнет, не выдерживая конкуренции других видов растений (Клименко и Мельничук, 2005).

В то же время в культуре на периодически обрабатываемых приствольных кругах, как это имеет место в насаждениях НБС, самосев образуется в пределах кроны, где приствольные круги мульчируются, плоды опадают и семена прорастают по мере того, как мульча перегнивает, и создаются условия для их прорастания (Клименко, 2013).

Сеянцы кизила используют как подвой при размножении окулировкой. Это единственный подвой для кизила. Мы испытывали как подвои разные виды кизила, но, кроме кизила лекарственного, ни один из других видов кизилов не совместим с кизилом обыкновенным так как они очень далеки в систематическом отношении.

Несмотря на то, что семенной способ размножения кизила не утратил значения для выращивании подвоя, а также сеянцев для создания лесных культур, при создании моносадов из кизила необходимо размножение перспективных форм вегетативно, поскольку семенной способ размножения не обеспечивает закрепления в потомстве всех хозяйственно ценных признаков сорта. Кроме того, сеянцы кизила начинают плодоносить лишь на 6 - 8-й год, а вегетативно размноженные растения - на 2 - 3-й год.

Известно, что каждая форма растений размножается преимущественно одним из способов - вегетативным или семенным. Размножение одного и того же вида одинаково легко и вегетативно и семенами не наблюдается. Большую или меньшую способность какой-либо породы к вегетативному размножению, присущий ей морфофизиологический тип корнеобразования связывают с условиями происхождения (Правдин, 1938). Основой такого подхода является сравнительное экологическое учение о развитии растительности 
в сочетании с климатическими, почвенными и биологическими условиями существования, космическими и земными факторами среды.

Очевидно, что способность растений к вегетативному размножению генетически обусловлена.

Существует прямая зависимость способности породы к придаточному корнеобразованию от характера внешних условий, формирующих наследственную природу вида. Среди этих условий первое место занимает влага. Считают, что растения, которые легко укореняются, формировались во влажных регионах (Правдин, 1938; Фаустов, 1985).

Кизил в природе растет на сухих склонах южных экспозиций и почвах, сформированных на карбонатных породах (рис. 5). Этим, по-видимому, и объясняется его плохое укоренение без влагообеспечения. Способность хорошо укореняться в условиях повышенной влажности подтверждает мысль о том, что когда-то существовали природные древние леса с участием кизила и при других условиях - на юге и востоке Приднепровской возвышенности, что позволяет считать кизил реликтом позднего плиоцена - видом, пережившим похолодание в четвертичном периоде in situ (Удра, 1984).
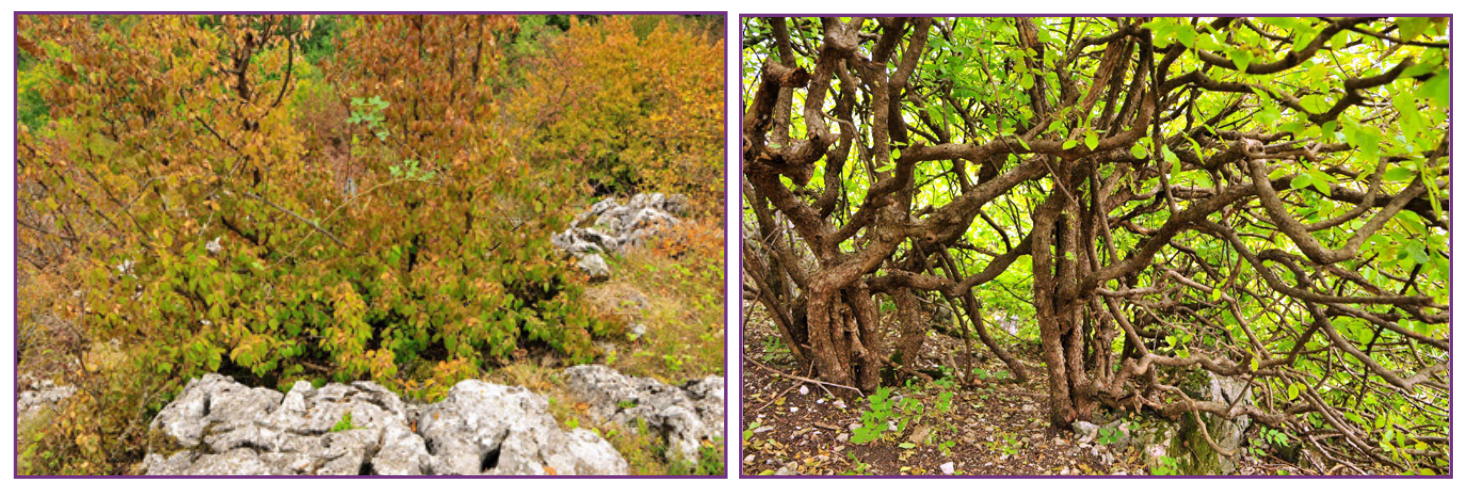

Рисунок 5 Вековые растения кизила в природе

Figure 5 Age-old cornelian cherry plants in nature

Размножение кизила в природе обусловлено усиленной способностью к образованию поросли. Этот тип образования молодых побегов продолжается в течение многих лет вследствие непрерывного восстановления надземной части взамен отмирающих придаточных стволов. В Винницкой, Закарпатской (Чорная гора), Кировоградской (Цыбульово - Черный лес), Ивано-Франковской, Тернопольской, Черкасской (село Деренковец, Чигирин), областях в местах природного произрастания кизила мы наблюдали порослевые куртины кизила с несколькими десятками штамбов, образовавшихся по периферии огромных старых пней, которые некогда были главными (первичными, центральными) штамбами (Клименко и Мельничук, 2005).

Такие же старые деревья (возрастом 100 - 150 лет и более) каждое с несколькими десятками штамбов мы наблюдали и в культуре: в Винницкой, Днепропетровской (Демурино-Варваровка), Житомирской, Закарпатской, Ивано-Франковской, Киевской, Львовской, Тернопольской, Хмельницкой (село Лавриновцы), Черкасской областях и в Крыму (в старых татарских садах).

Склонность в природе к образованию многочисленной корневой поросли, очевидно, компенсирует ослабленную способность кизила к размножению семенами. Способностью кизила образовывать большое количество порослевых побегов обусловлена его долговечность (Клименко и Мельничук, 2005). 
Поддержание и сохранение природных популяций кизила основано на вегетативном размножении - репродуктивной регенерации вследствие непрерывного восстановления надземной части взамен отмирания придаточных стволов. В условиях достаточного увлажнения наблюдается усиленный ризогенез на стеблях, наклоненных к земле или засыпанных ею.

Вегетативное размножение кизила в природных условиях, очевидно, является его особенностью, обеспечивающей выживание вида, однако, как считает И.Ф. Удра (1984), оно не обеспечивает сохранение кизила на протяжении длительного геологического периода. Этот вид размножения имеет значение в сочетании с семенным, которое способствует захвату новых территорий.

В природе вегетативное размножение кизила преобладает над семенным. Для отдельных представителей покрытосеменных растений вегетативное размножение, как отмечает В.В. Фаустов (1985), является единственным способом возобновления.

Форма репродуктивной регенерации - восстановление целостного организма из части (корневищами, отпрысками, порослью, отводками) широко распространена в естественном мире (Кренке, 1950; Фаустов, 1985). Отмечается, что процессы регенерации и способы вегетативного размножения у цветковых растений в сравнении с низшими более сложны и специализированы, особенно в суровых условиях среды обитания. Например, многие представители цветковых растений в аридной зоне переходят на преимущественно вегетативное размножение. По данным В.И. Запрягаевой (1964) в крайне засушливых аридных редколесьях Средней Азии у дикорастущих плодовых растений семенное размножение подавлено и превалирует вегетативное, особенно у грецкого ореха, инжира, хурмы, облепихи, граната, ююбы, многих видов яблони, груши, сливы, рябины, лоха, ежевики и др. Наличие нескольких форм размножения, включая и вегетативное, приобретает «первостепенную важность в стратегии выживания и процветания высших растений» (Фаустов, 1985).

Однако, как считают исследователи (Удра, 1988) вегетативное размножение, хотя и способствует закреплению вида вблизи материнской особи и в определенных пределах переживанию им экстремальных условий, все же не обеспечивает его сохранности в течение длительного геологического периода. При помощи вегетативного размножения растения расселяются на очень незначительные расстояния (за исключением видов, способных к придаточному корнеобразованию) в пределах нескольких сантиметров или десятков сантиметров в год. Поэтому при изучении расселения, особенно миграционныхспособностей, надо анализировать все этапы его генеративного размножения, а не только дессиминацию.

В культуре вегетативное размножение используется для получения материала без изменения генотипа. Оно, как форма неполового размножения, осуществляется соматическими частями стеблевыми и корневыми черенками, отводками, прививкой стеблевыми черенками, почкой (окулировка) (рис. 6).

\section{Размножение черенками}

Зелеными и особенно одревесневшими черенками в обычных условиях кизил размножается плохо. Однако в условиях повышенной влажности и температуры, а также при обработке черенков физиологически активными веществами значительно увеличивается количество укорененных черенков, общее количество корней и их суммарная длина (Балабак, 1990; Надточій, 2005).

Оптимальные условия для черенкования зелеными (летними) черенками, по нашим данным: влажность 95 - $100 \%$, температура 24 - $28{ }^{\circ} \mathrm{C}$, субстрат - торф и песок в соотношении $1: 1$, толщина слоя 25 - 30 см, верхний слой толщиной 4 - 5 см - чистый песок (Клименко, 2000). 

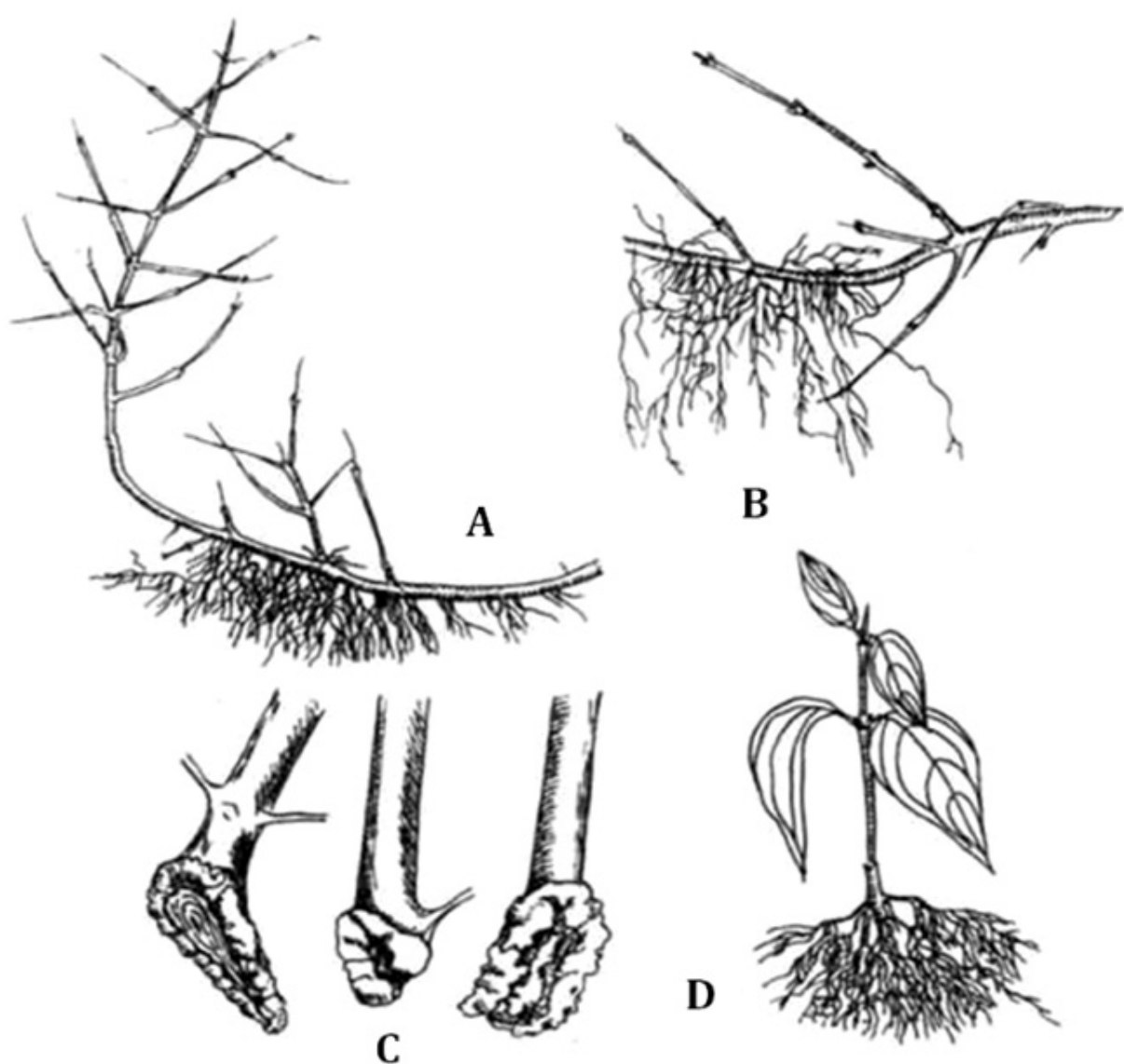

D
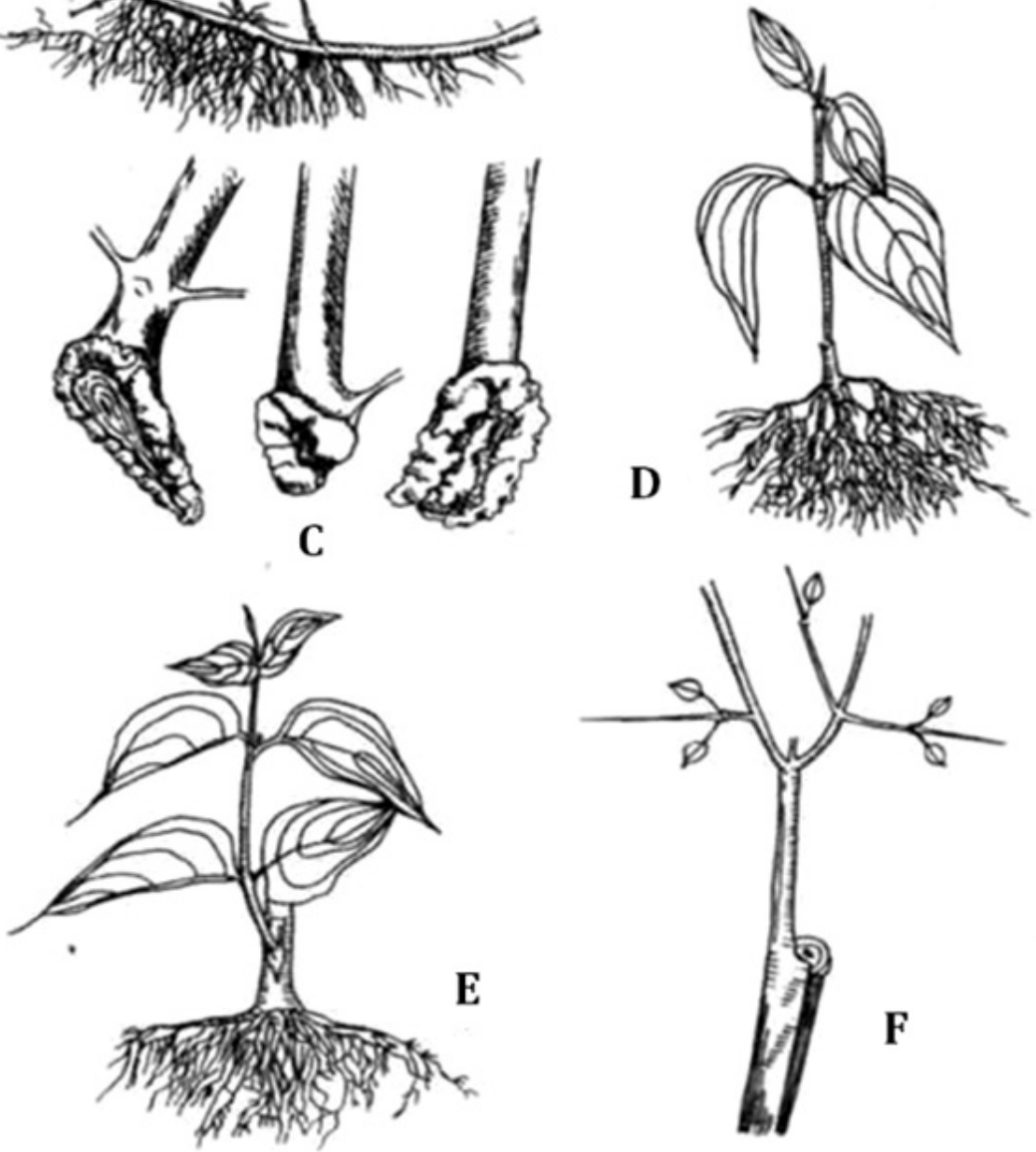

\section{Рисунок 6 Вегетативное размножение кизила}

A, B - укорененные отводки; C - одревесневшие черенки с каллюсом; D - укорененный зеленый черенок; $\mathrm{E}$ - окулянт кизила (летняя окулировка глазком); $\mathrm{F}$ - двухлетняя привитая ветка кизила (весенняя прививка)

Figure 6 Vegetative reproduction of the cornelian cherry

A, B - rooted layers; C - lignified cuttings with callus; D - rooted green cutting; E - grafted plant (summer budding); F - two-year-old grafted cornelian cherry branch (spring graft) 
Оптимальные сроки черенкования летними черенками совпадают с периодом интенсивного роста побегов, в условиях Лесостепи Украины это приходится на I - III декады мая - I декаду июня.

Сроки заготовки черенков ежегодно варьируют до двух-трех недель и зависят от погодных условий, возраста и состояния маточных растений. Надо сказать, что мы испытывали разные сроки заготовки черенков, как ранние, так и более поздние. Основными факторами при определении сроков заготовки черенков являются период активного роста и небольшое одревеснение нижней части побега.

С увеличением длины побега и его возраста регенерационная способность значительно снижается, процент укоренения ниже, корневая система, образовавшаяся только у части черенков, слабее (Надточій, 2005).

Стимуляторы роста очень способствуют укоренению черенков, их присутствие активизирует деятельность нативных ауксинов, которые вырабатываются растениями. У кизила при зеленом черенковании нельзя укорачивать листовые пластинки с целью уменьшения транспирации, так как они являются источником образования органических веществ. Уменьшить транспирацию можно другими способами, например, герметизацией. У черенков с целыми листьями происходит более быстрое и интенсивное нарастание корней в сравнении с черенками, подготовленными традиционным способом. От площади листьев зависит количество и длина корней, которые образуются при черенковании. Укоренение начинается через 12 - 15 дней и полностью заканчивается через 45 - 60 дней. Пересадку укорененных черенков на доращивание надо проводить осенью в контейнеры, а весной - можно и в открытый грунт (Клименко, 2000).

Как показали наши исследования, высадка растений в открытый грунт осенью чревата потерей растений из-за плохой перезимовки, растения слабо укореняются и выпадают. Высаживали растения в октябре, в более ранние сроки корневая система черенков недостаточно развита. Осеннее высаживание растений в контейнеры обеспечило хорошую перезимовку растений. Весенняя пересадка укорененных черенков, оставленных на зиму в туманообразующей установке была успешнее - 80 \% прижившихся растений в сравнении с $40 \%$ - при осенней посадке в открытый грунт. Схема высадки растений в обоих случаях была одинаковой 35 - 40 см между рядами и 15 см между растениями в ряду (Клименко, 2000).

\section{Размножение окулировкой}

В наших исследованиях - это эффективный способ размножения. Он обеспечивает получение достаточного количества саженцев, которые отвечают требованиям производства.

Окулировку надо делать в период повышенной физиологической активности подвоев и привоев. В условиях Лесостепи Украины лучшие сроки окулировки кизила - с 25 июля до конца августа.

Сложилось мнение (Нароян, 1951), что окулировка, как способ размножения, для кизила неприемлема. Вероятно, это произошло из-за недостатка экспериментальных исследований. В Абхазии окулировку применил Л.Х. Хашба (1962).

К привитым растениям в полной мере относятся закономерности старения и омоложения растений, вегетативно размноженных собственными корнями. Омолаживающее влияние при прививке определяется совместимостью привоя и подвоя. Очень важным обстоятельством при этом является обогащение природы растения.

При соединении двух наследственных основ появляются большие возможности управления ростом и плодоношением растений в разнообразных условиях.

Несмотря на то, что при прививке разрезают ткани, у привитых растений при удачном подборе привоя и подвоя не наблюдается признаков угнетения. Разрезанные ткани привоя и подвоя 
быстро срастаются, и привитые части дают сильный прирост. Это особенно видно на примере кизила, так как в основном его размножают семенами и получают сеянцы, достигающие в 1-й год небольших размеров - 30 - 35 см, диаметр штамба - 0,4 - 0,5 см, с мелкими листьями (рис. 7), а окулянты в 1-й же вегетационный период достигают значительных размеров - 100 - 130 см, диаметр штамба - 1,3 - 1,5 см (рис. 8).

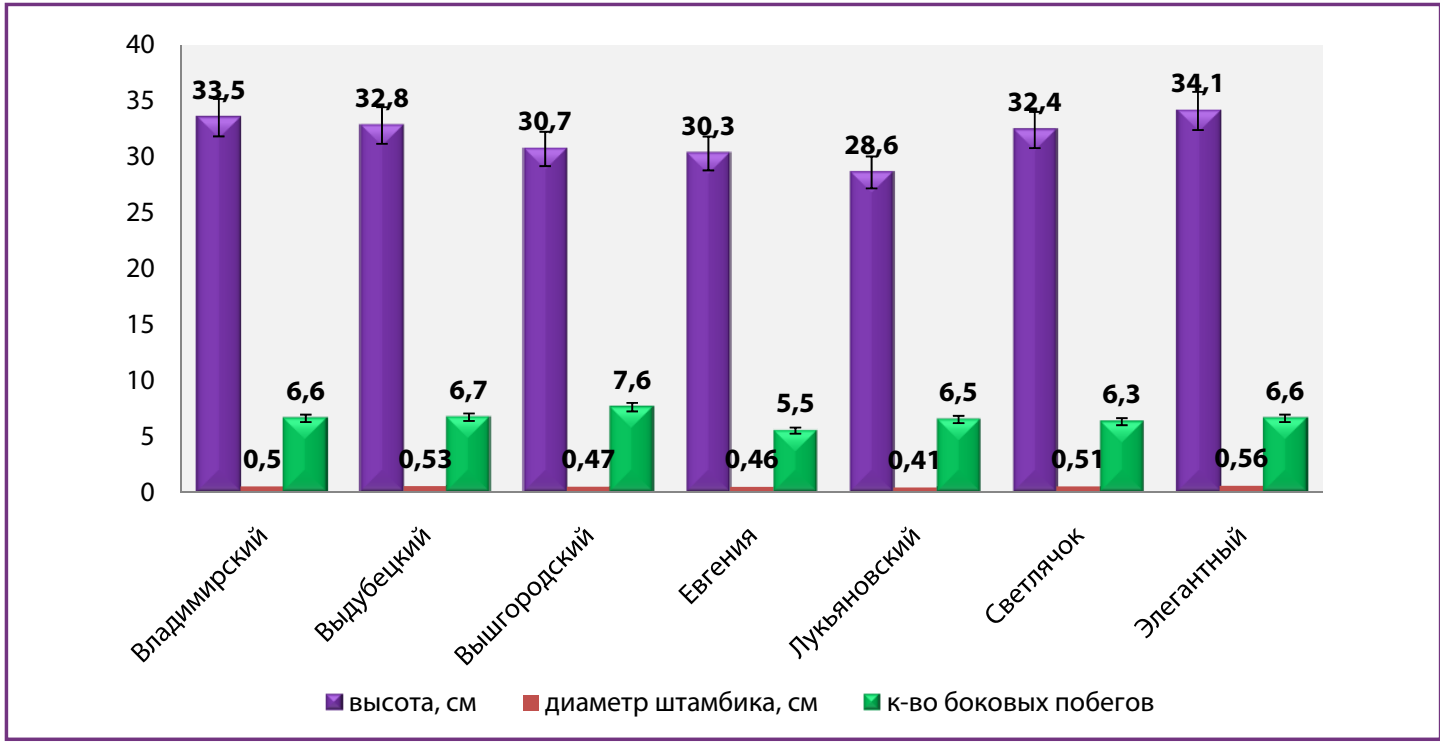

Рисунок 7 Средние показатели роста однолетних сеянцев кизила (2005 г)

Figure 7 Average growth rates of annual seedlings of cornelian cherry (2005)

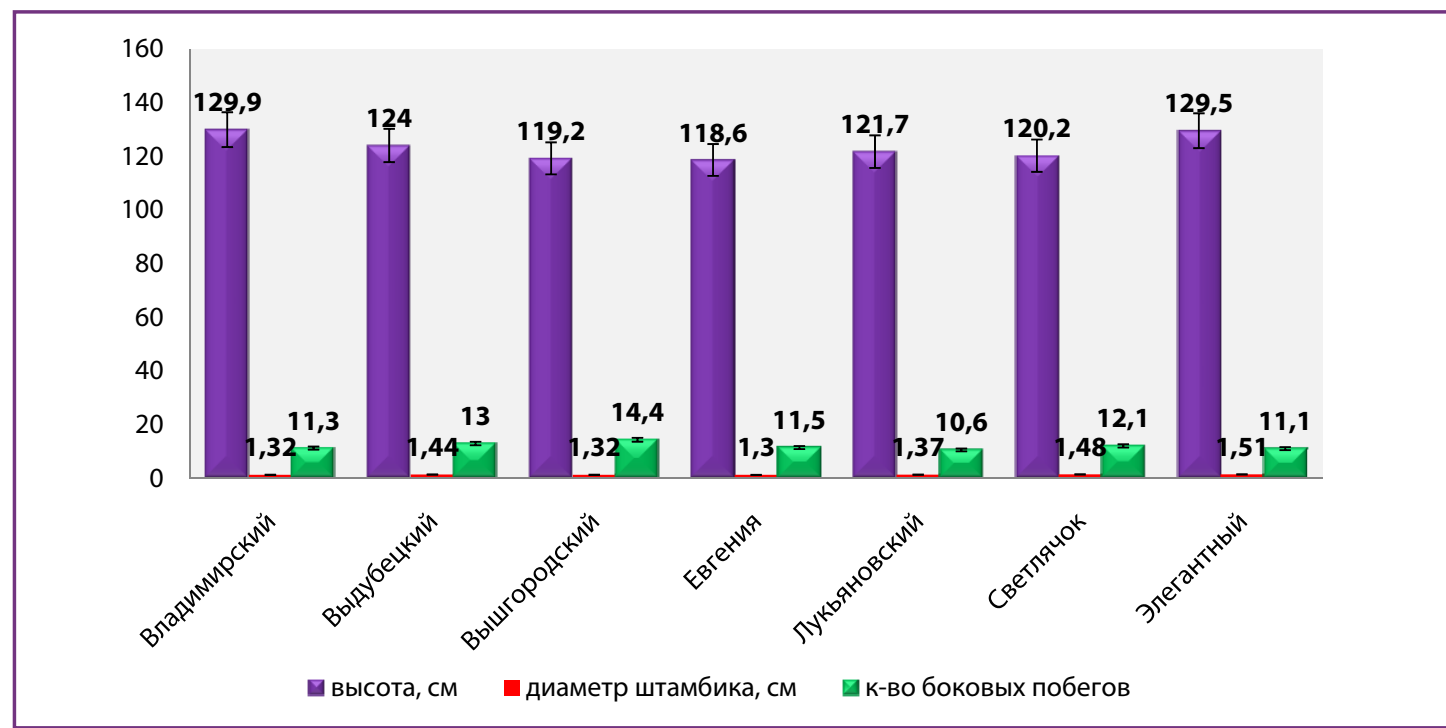

Рисунок 8 Средние показатели роста однолетних окулянтов кизила (2005 г)

Figure 8 Average growth rates of annual cornelian cherry grafted plants (2005) 
Листья привитых растений кизила крупные, с ярко выраженным жилкованием. У однолетних окулянтов за вегетационный период образуется 4 - 7 боковых побега, так что уже в этом возрасте их можно высаживать на постоянное место. В хороших условиях культуры молодые саженцы кизила очень развиты: они имеют крепкий штамбик, хороший вегетативный прирост, крупные плоды, растения быстро растут и интенсивно плодоносят. Самое большое достоинство окулировки у кизила - это то, что привитые растения уже на 3-й, а часто и на 2-й год плодоносят, а 3 - 4-летний саженец дает 3 - 5 кг плодов. Сеянцы, как известно, начинают плодоносить на 5 - 8-й год.

\section{Размножение весенней прививкой}

Этот способ очень часто используют для размножения кизила. Приживаемость составляет от 40 до 70 \% и очень зависит от сроков, состояния растений и техники. Хорошие результаты получены в наших исследованиях прививкой в боковой зарез, вприклад и улучшенной копулировкой. Наиболее благоприятным для прививки в условиях Лесостепи Украины является период с третьей декады марта до конца апреля (во время цветения растений). Используют разные способы прививки, но чаще всего - прививку в расщеп и за кору. Весенняя прививка удается хуже, чем летняя.

В своих опытах мы с успехом испытали и летнюю прививку (окулировку) на плодоносящих растениях - на ветках в нижней части кроны, где глазки очень хорошо приживались. Прививали 10 - 15 сортов на одном дереве и прививки уже через год вступали в плодоношение.

\section{Размножение отводками}

Это один из старых способов, который используется в садоводстве. Метод размножения состоит в стимулировании образования корней на стебле до отделения его от материнского растения.

Если образование корней на отводках хорошее, их выкапывают осенью, в октябре. За 3 - 4 недели до высаживания отводки отделяют от материнского растения, чтобы вновь образовавшиеся растения приспособились к условиям самостоятельного существования. Хорошо укоренившийся отводок выкапывают и высаживают в питомник или на постоянное место. Если же к осени корневая система достаточно не сформировалась, отводок оставляют еще на одну вегетацию.

Чем старше укорененная ветка, тем быстрее начинает плодоносить отводок - будущий саженец. Отводки из трехлетних веток начинают плодоносить уже в первый год после укоренения, из однолетних - на второй или третий год. Количество отводков, полученных с одного растения, зависит от его возраста и габитуса. С одного экземпляра можно получать в зависимости от возраста растения 5 - 8 отводков.

\section{Выводы}

Современное состояние кизила в природе обусловлено экстремальными условиями его произрастания, запасы его в природе существенно сократились. В последние десятилетия в Украине, как и в других странах, интерес к кизилу значительно возрос, однако не удовлетворяется спрос на сортовой посадочный материал из-за недостаточно опробованных способов семенного и вегетативного размножения. Вопросами размножения кизила занимается отдел акклиматизации плодовых растений НБС, селекционный фонд которого представлен несколькими десятками сортов, 14 из них внесены в Государственный Реестр сортов растений Украины (Клименко, 2013).

Изучены способы семенного и вегетативного размножения. Показано, что для размножения семенами эффективна двухэтапная стратификация - теплая $\left(20-25{ }^{\circ} \mathrm{C}\right)$ в течение $3-4$ месяцев и холодная $\left(+3-5^{\circ} \mathrm{C}\right)$ в течение 4-х месяцев. Эндокарп, по нашим данным, не 
является препятствием для прорастания семени: количество поглощенной им воды на 9 - 11 сутки составляет $125 \%$. Анатомическое строение эндокарпа свидетельствует о тесной связи с оболочкой семени и наличии в последнем ингибиторов, тормозящих прорастание. Ингибиторы удаляются при достаточном обеспечении семян водой.

Семенное восстановление кизила в природе затруднено в связи с его биологическими особенностями и, прежде всего, требовательностью к освещению. Самосев кизила в природе образуется в незначительном количестве.

Размножение кизила в природе обусловлено усиленной способностью к образованию поросли. Этот тип образования молодых побегов продолжается в течение многих десятков лет вследствие непрерывного восстановления надземной части взамен отмирающих придаточных стволов. Склонность в природе к образованию многочисленной корневой поросли, очевидно, компенсирует ослабленную способность кизила к размножению семенами.

Способностью кизила образовывать большое количество порослевых побегов обусловлена его долговечность. В культуре эта способность кизила проявляется в хорошем размножении отводками. Несмотря на то, что семенной способ размножения кизила не утратил значения для выращивания подвоя, а также сеянцев для создания лесных культур, при создании моносадов из кизила необходимо размножение перспективных форм вегетативно, поскольку семенной способ размножения не обеспечивает закрепления в потомстве всех хозяйственно ценных признаков сорта. Кроме того, сеянцы начинают плодоносить лишь на 6 - 8-й год, а вегетативно размноженные растения - на 2 - 3-й год. Эффективное вегетативное размножение кизила зелеными черенками (75 - 80 \%), менее успешное (40 - $60 \%)$ - одревесневшими черенками обеспечивается условиями достаточного увлажнения (95 - 100 \%) и температуры $\left(+25-28^{\circ} \mathrm{C}\right)$.

Для получения из укорененных черенков стандартных саженцев уходит два года. При хорошем уходе к концу первого вегетационного периода саженцы достигают высоты 35 - 50 см, второго 100 - 130 см, на втором году образуется 3 - 5 боковых побегов, и саженцы готовы для высадки на постоянное место.

Количество отводков, полученных с одного растения, зависит от его возраста и габитуса. С одного экземпляра можно получить 5 - 8 отводков. Размножение отводками биологически эффективно, однако для массового получения саженцев более трудоемкое, чем другие способы вегетативного размножения, он успешно может использоваться в фермерском садоводстве.

Летняя прививка (окулировка) дает высокий выход привитого материала, однолетние окулянты достигают высоты 100 - 130 см, диаметр штамба составляет 1,3 - 1,5 см, в этом возрасте они могут быть высажены на постоянное место. Лучшие сроки проведения окулировки в Лесостепи Украины - конец июля - август. При достаточном количестве осадков сроки окулировки могут быть продлены до II декады сентября.

Весенняя прививка проводится во время цветения - в апреле, она - менее эффективна, чем летняя.

Наиболее эффективные методы вегетативного размножения - окулировка и размножение зелеными черенками.

Выход посадочного материала при размножении кизила летней прививкой (окулировкой) составляет 90 - $95 \%$, отводками - 85 - $90 \%$, зелеными черенками - 75 - $80 \%$, одревесневшими черенками - 40 - $60 \%$, весенней прививкой $-40-60 \%$.

Любой из предложенных способов вегетативного размножения может использоваться как в фермерских садах, так и в промышленных масштабах для массового получения сортового посадочного материала. 


\section{Литература}

Chopra, R.N. 1965. Kaw Harjinder. Some aspects of the embryology of Cornus. Phytomorphology, vol. 15, no. 4, p. 353-359.

Erdelska, O., Szukukalek, A. 1980. Prispevok k embryologickemu stadium driena Cornus mas L. Zb. ref. z 3-go ziazdu Slov. Bot. spolocn. pri SAV Zvolen, p. 271-274.

Seely, S.D., Damavandy, H. 1985. Response of seed of seven deciduous fruits to stratification temperatures and implications for modelling. Journal American Society Horticultural Sciencies, no. 5, p. 726-729.

Suszka, B. 2002. Przedsiewne przysposabianie nasion drzew i krzewów do kiełkowania. Szkółkarstwo, no. 3, p. 18-19.

Tylkowski, T. 1991. Thermal conditions for the after - ripening and germination of Cornelian cherry (Cornus mas L.) seeds. Arbor. Kor., 36, p. 165-172.

Ализаде, 3.М., Мамедов, Ш.Ш. 1997. Особенности семенного размножения кизила обыкновенного. Шекин. регион. науч. Центр АН Азерб. Респ. Шеки. 7 с.

Балабак, А.Ф. 1990. Вплив ростових речовин на регенераційну здатність різнотипних живців кизилу. Дослідження проблем природознавства, техніки, сільського господарства. Черкаси, с. 26-27.

Вановский, П.Я., Воронцов, Ф.К. 1952. Ускорение стратификации лесных семян. Лесное хозяйство, № 9, с. 22-27.

Дудукал, Г.Д. 1989. Как вырастить кизил из косточек. Садоводство и виноградарство Молдавиии, № 7, с. 60.

Запрягаева, В.И. 1964. Дикорастущие плодовые Таджикистана. М.; Л. 695 с.

Ильина, А.И. 1952. Кизил как плодовое дерево Крыма : автореф. дис. канд. биол. наук. Л. 20 с.

Іванніков, Д.В. 1999. Прискорене пророщування насіння кизилу за допомогою біологічних стимуляторів росту. Садівництво, вип. 49, с. 178-182.

Кащенко, М.Ф. 1925. На допомогу київському Акліматизаційному садові. К. 27 с.

Клименко, С.В. 1990. Кизил на Украине. Киев: Наукова думка. 174 с.

Клименко, С.В. 2000. Кизил в Україні. Біологія, вирощування, сорти. Київ: Укрфітосоціоцентр. 92 с.

Клименко, С.В. 2013. Кизил. Каталог сортов. К: НПП «Интерсервис». 72 с.

Клименко, С.B., Мельничук, О.А. 2005. Формирование природных популяций кизила (Cornus mas L.) В связи с регенерационной способностью. Проблеми збереження, відновлення та збагачення біорізноманітності в умовах антропогенно зміненого середовища. Матер. міжнар. конф. Дніпропетровськ: Проспект, с. 104-106.

Клименко, С.В., Скрипка, Е.В. 1987. Морфология семени. 8 съезд Укр. ботан. общ-ва: тез. докл. ИваноФранковск, С. 38.

Клименко, С.В., Скрипка, Е.В., Жолтонога, Д.Д. 1988. Морфологическое разнообразие плодов и эндокарпов кизила. Интрод. и акклимат. раст., вып. 9, с. 80-84.

Колотова, М.Г. 1982. К вопросу получения всходов кизила. Труды Арерб. НИИ садоводства, № 6, c. 287-297.

Кренке, Н.П. 1950. Регенерация растений. М. Л.: Изд-во Моск.ун-та. 675 с.

Литвиненко, С.H. 1955. Изучение некоторых биологических особенностей кизила (Cornus mas L.) и выявление лучших форм в условиях Киева : Автореф. дис. ... канд. биол. наук. Киев. 20 с.

Майборода, В.П. 2003. Стратифікація насіння. Новини садівництва, № 3, с. 6.

Минин, Д.Д. 1962. Хранение и подготовка к посеву семян древесных, кустарниковых пород. М.: сельхозгиз. 120 с.

Надточій, І.П. 1998. Вплив способів передпосівної обробки насіння кизилу на його проростання. Садівництво. Міжвідомчий тематичний збірник, № 47, с. 213-216. 
Надточій, І.П. 2005. Вплив строків живцювання і метамерності зелених живців малопоширених садових культур на їх укорінення в умовах штучного туману. Вісн. ДАУ. Агроекологія, № 1, с. 57-63. Николаева, М.Г. 1967. Физиология глубокого покоя. Л.: Наука. 206 с.

Парфенова, Т.М. 1974. Влияние предпосевной подготовки на ускорение прорастания и на морфологические изменения семян кизила. Биол. основы семеноведения и семеноводства интродуцентов. Новосибирск: Наука, с. 216-218.

Правдин, Л.Ф. 1938. Вегетативное размножение растений. М.-Л.: Огиз. Сельхозгиз. 232 с.

Радулов, Д. 1996. Предсеитбена стратификация на дряна. Агроколтас, вип. 12, № 2, с. 4-5.

Сорта плодовых и ягодных растений селекции Национального ботанического сада им. Н.Н. Гришко. 2013. Под ред. С.В. Клименко. Киев: Фитосоциоцентр. 104 с.

Удра, И.Ф. 1984. Cornus mas (Cornaceae) на Украине - реликт третичных лесов. Ботан. журн., № 1, C. 33-42.

Фаустов, В.В. 1985. Проблема регенерации и вегетативного размножения в садоводстве. Проблемы вегетативного размножения, С. 21-32.

Хашба, Л.Х. 1962. Размножать лучшие сорта и формы кизила. Сухуми: Абгосиздат. 23 с. 